\title{
Imagining Africa in Eastern Europe: Transcultural Psychiatry and Psychoanalysis in Cold War Yugoslavia
}

\author{
Ana Antić* \\ University of Exeter, Department of History, Amory A129b, Rennes Drive, Streatham Campus, Exeter EX4 4RJ \\ *a.antic@exeter.ac.uk
}

This article seeks to write Yugoslavia and Eastern Europe into the history of post-Second World War global psychiatry and to explore the significance of Marxist psychiatry in an international context. It traces Yugoslav psychiatrists' transnational and interdisciplinary engagements as they peaked in the 1960s. Focusing on the distinguished Belgrade psychiatrist and psychoanalyst Vladimir Jakovljevic (192568), it looks at Yugoslav psychiatry's clinical and anthropological research in the global South to shed light on its contributions to Western-dominated transcultural psychiatry. Through this lens the article also explores how Eastern Europe's intellectuals engaged with decolonisation and the notions of race, 'primitivism' and modernity. Jakovljevic's involvement in transcultural psychiatry demonstrated the inherent contradiction of Eastern European Marxist psychiatry: its dubiously colonial 'civilising mission' towards the subalterns in its own populations and its progressive, emancipatory agenda. Jakovljevic's writings about Africa ultimately turned into an unprecedented opportunity to shed light on some glaring internal inconsistencies from Yugoslavia's own socio-political context.

After the Tito-Stalin split of 1948, when socialist Yugoslavia exited the Soviet-dominated bloc and strengthened its relations with both the West and the non-aligned movement, Yugoslav psychiatrists (alongside other medical experts) positioned themselves at the centre of a dynamic and ever shifting world. They could claim to have insights into both ideological camps while maintaining their critical distance and attempting to craft an original approach to understanding the medical, social and political aspects of mental abnormality. From the early 1950s on they quickly became integrated into Western European and North American psychoanalytic and psychotherapeutic professional and research networks, although their strong interest in reconciling Marxism with psychoanalysis set them apart from their Western peers in certain respects. However, their relationship with the Soviet Bloc significantly improved after Stalin's death, so that some mental health practitioners' experimentation with Pavlovian psychology and interest in Soviet mental healthcare added to the profession's eclecticism and cosmopolitanism. ${ }^{1}$ Finally, Yugoslav psychiatrists embarked on lengthy educational and advisory trips to the non-aligned world which allowed them to conduct sociological, medical, psychiatric and anthropological research in the non-Western territories.

When faced with the budding field of cross-cultural research in international psychiatry from the mid-1950s on, Yugoslav psychiatrists considered themselves well placed to explore the transcultural sociological and political aspects of mental illness and to contribute to comparative global studies on psychiatric normativity, epidemiology and universal diagnostic techniques.

\footnotetext{
1 See, for instance, Nikola Nikolić, 'Vladimir Iljić Lenjin i Zaštita Narodnog Zdravlja', Medicinski Glasnik, 1, 5 (1947); G. Nikolić, 'Oktobarska Revolucija i Razvoj Sovjetske Medicine’, Vojno-Sanitetski Pregled, 4, 11-2 (1947); V. Stojanović, 'Velika Oktobarska Revolucija i Zaštita Narodnog Zdravlja u SSSR', Medicinski Glasnik, 2, 2 (1947); Nikola Nikolić, 'Razvice Sovjetske Medicine', Medicinski Glasnik, 1, 9 (1947).
} 
Combining a variety of theoretical approaches and research interests, a small group of psychiatrists, psychoanalysts and other 'psy' experts from Yugoslavia worked to develop culturally sensitive but globally applicable norms for diagnosing mental illness and for defining its social, cultural and anthropological elements, causes and consequences. This article traces such transnational and interdisciplinary engagements as they peaked in the 1960s. Focusing on the distinguished Belgrade psychiatrist and psychoanalyst Vladimir Jakovljevic (1925-68), it looks at Yugoslav psychiatry's clinical and anthropological research in the global South to shed light on its contributions to Western-dominated global transcultural psychiatry. Through this lens, the article also explores Eastern Europe's political engagement with decolonisation and the notions of race, 'primitivism' and modernity.

In particular, the article considers Jakovljevic's work in Guinea, the former French colony in West Africa, where he spent over thirty months (1961-3) as a clinical and research psychiatrist and a member of the technical aid mission financed by Yugoslavia's Federal Bureau for international scientific, educational-cultural and technical cooperation. ${ }^{2}$ Jakovljevic was the most prominent Yugoslav psychiatrist to participate in any professional or clinical exchange with the decolonising world, as well as the most prolific one, publishing numerous reports, books and journal articles on his involvement in Guinea and its implications for the field of transcultural psychiatry. He was the pioneer of Yugoslavia's (and Eastern Europe's) transcultural psychiatric research and quickly became the leading figure in that field in the regional context. ${ }^{3}$

By tracing Yugoslav psychiatrists' efforts to establish links and communication models between Western, Eastern and (global) Southern epistemological systems and networks, this article aims to inscribe the region of Eastern Europe into the broader history of global medical and psychiatric knowledge production. ${ }^{4}$ Jakovljevic - a Marxist psychiatrist educated in France and deeply interested in French and British psychoanalysis and psychotherapy - personifies the in-between position inhabited by Yugoslav researchers and clinicians; here, I analyse how such political, ideological and geographical-cultural displacement moulded his and his Yugoslav colleagues' interventions in the field of transcultural psychiatry. Jakovljevic's 'in-betweenness' was multidimensional. Geographically and culturally he was caught between Western Europe (the home of transcultural psychiatry) and a small Balkan country, whose own developmental stage was questionable and uncertain. Ideologically, even though he declared himself a committed communist, Jakovljevic's affiliation was to a non-Soviet, non-aligned form of socialism, which meant that his approach to social and mental health problems in the 'Third World' was a combination of Marxist (even Soviet) psychiatric concerns, West European theoretical frameworks and ideas of workers' self-management and non-aligned solidarity. Finally, as a socialist Eastern European psychiatrist, Jakovljevic was extremely critical of the legacies of Western colonialism, but as a prominent transcultural psychiatrist he never managed to completely break out of the profession's lingering colonial paradigm: as he grappled with the concepts of primitivism, backwardness and decolonisation, Jakovljevic combined colonial and anti-colonial

\footnotetext{
2 Archive of Yugoslavia, Savezni zavod za medjunarodnu naucnu, prosvetno-kulturnu i tehnicku saradnju, F-465 box 545 , 'Opsti dosije'; box 1645, 'Naucno-tehnicka saradnja SFRJ-Gvineja'.

3 Petar Klajn, Razvoj Psihoanalize u Srbiji (Belgrade: Pedagoska akademija, 1989).

4 The literature on Cold War encounters between the socialist bloc and the 'Third World' is growing, and it largely focuses on networks of experts and university student exchanges, while the history of medical collaboration remains neglected for the most part. See Maxim Matusevich, 'Revisiting the Soviet Moment in Sub-Saharan Africa', History Compass, 10 (July 2009), 1-10; Matusevich, 'Probing the Limits of Internationalism: African Students Confront Soviet Ritual', Anthropology of East Europe Review, 27, 2 (Oct. 2009), 19-39; Benjamin Tromly, 'Brother or Other? East European Students in Soviet Higher Education Establishments, 1948-1956', European History Quarterly, 44, 1 (2014), 80-102; Lukasz Stanek, 'Architects from Socialist Countries in Ghana (1957-1967): Modern Architecture and Mondialisation', Society of Architectural Historians' Journal, 74, 4 (2015), 416-42; Stanek, 'Mobilities of Architecture in the Late Cold War: From Socialist Poland to Kuwait, and Back', International Journal of Islamic Architecture, 4, 2 (2015), 365-98.
} 
discourses to try to define the global position and developmental possibilities of the decolonising world.

One crucial consequence of Jakovljevic's complex background was his complicated and constantly changing relationship to his Guinean area of study: he was a white European researcher but emphatically not Western in a crucial political/ideological sense, and a representative of a state which consciously strove to offer a communist alternative to the Western colonial project. ${ }^{5}$ The article explores how Jakovljevic's global engagements were ultimately driven by his domestic concerns - his implicit perception of the fundamental similarity between Guinea and Yugoslavia as two 'backward' and rapidly modernising societies. While he never explicitly drew parallels between Yugoslavia and any African country, this article close reads Jakovljevic's texts in order to reveal the similarity of his analyses of and conclusions about the two regions, and to interrogate Jakovljevic's uncertainty regarding the cultural-geographic and civilisational position of socialist Yugoslavia.

In this article I also aim to demonstrate that such transcultural involvements exposed some of the core ideological and conceptual inconsistencies within Marxist psychiatry in Eastern Europe. ${ }^{6}$ Jakovljevic's contradictory relationship to colonial legacies was not simply a function of his education in (Western European) transcultural psychiatry; it should also be placed in the context of Marxism's (and Marxist psychiatry's) own 'civilising mission'. One of the core debates in Yugoslavia's socialist psychiatry revolved around the problem of 'primitive' patients, and the psychiatrists' role in modernising those 'archaic' and 'uncultured' sections of the population. Because of the multiple meanings of 'primitivism' in the Yugoslav psychiatric context, Jakovljevic applied the same language of backwardness and civilisation to his Macedonian and Guinean patients, and, consequently, there were no fundamental differences in his descriptions of the developmental stages of the two regions.

\section{The Biography of a Pioneer}

Jakovljevic belonged to one of the first post-Second World War generations of Yugoslav psychiatrists. Graduating from the Medical Faculty in Zagreb in 1951, he completed specialisations in neuropsychiatry at several clinics in Yugoslavia as well as a one-year postgraduate psychoanalytic training in Paris (1956-7). Before settling in Belgrade he spent three years as a psychiatric clinician, researcher and teacher in Skopje, Macedonia, Yugoslavia's southernmost republic and one of its most underdeveloped territories, which became very important for his subsequent contributions to comparative and transcultural psychiatry. Jakovljevic belonged to a powerful psychoanalytically oriented psychiatric and psychotherapeutic group gathered around the highly influential military psychiatrist Vladislav Klajn, the head of the neuropsychiatric ward in Belgrade's 'Dragisa Misovic' hospital, in which Jakovljevic himself was briefly employed. Throughout his varied career he was committed to reconciling modern psychoanalysis with humanist Marxism, Marxist anthropology and the core tenets of workers' self-management, a synthesis which remained the principal mission of Yugoslavia's post-war psychiatry.

The development of Marxist and socialist psychiatry in post-1945 Yugoslavia saw a radical departure from the previously dominant biological and organicist models, which interpreted mental illness as exclusively understood in the context of hereditary, constitutional and physiological deficiencies. As Marxist mental health professionals argued, these earlier paradigms conveniently ignored the pervasive pathological influences of socio-economic factors and contexts in capitalist societies and medicalised social conflicts and economic inequalities. In that

\footnotetext{
${ }^{5}$ For a recent discussion of the role of psychiatry and psychiatric concepts in the Western colonial project in the twentieth century, see Erik Linstrum, Ruling Minds: Psychology in the British Empire (Harvard University Press, 2016).

${ }^{6}$ On the history and intellectual frameworks of Marxist and communist psychiatry in Eastern Europe, see Ari Kiev, Psychiatry in the Communist World, (Science House, 1968); Mat Savelli and Sarah Marks, Psychiatry in Communist Europe (London: Palgrave Macmillan, 2015).
} 
sense, Yugoslav socialist psychiatry became increasingly interested in the social, psychological and environmental aspects of patients' experiences. ${ }^{7}$ As Jakovljevic wrote in his 1959 article on the sociopsychology of neuroses in Macedonia, the development of the concept of psychogenesis of mental illness in cultural psychiatry had enabled clinicians and researchers to 'disprove fatalist interpretations regarding the supposedly exclusively hereditary nature of a variety of [mental] disorders, including neuroses'. ${ }^{8}$ In addition, as the political experiment with workers' selfmanagement was underway, a growing number of both psychiatrists and social scientists began to explore the relationship between humanist Marxism, personal emancipation and psychoanalysis, and suggested that psychoanalytic techniques such as self-reflection and self-exploration might be central to achieving individual liberation and self-realisation in a self-managing context. ${ }^{9}$ Jakovljevic remained keenly interested in different psychoanalytic approaches as tools for personal liberation and development but still maintained a critical voice towards classical psychoanalysis and its tendency to eschew sociological analysis and focus predominantly on internal psychological conflicts and processes. Like Klajn he represented a sociologically oriented and materialist school of thought within psychoanalytic circles inspired by Karen Horney, Erich Fromm and Igor Caruso in particular. ${ }^{10}$ Jakovljevic was also something of an outsider to the profession because his sociological and anthropological interests led him, in 1963, to a professorship at the Faculty of Philosophy, rather than of medicine, at the University of Belgrade. ${ }^{11}$

Jakovljevic's Marxist orientation inspired his interest in the socio-economic and contextual determinants of mental pathology and his efforts to bridge disciplinary boundaries between psychiatry and social sciences. 'All internal (intra-psychic) conflicts', he opined, 'are, in the final analysis, merely intimate sediments of broader social conflicts, expressed to a greater or lesser extent in an individual personality. [Such mental disturbances] were conditioned by major imbalances within the core social institutions (family, class, social group), which were then reflected in the mental structure of an individual'. ${ }^{12}$ His proclaimed aim was not only to draw more attention to the socio-cultural aspects of mental health and abnormality but to 'bring together as much as possible medical and sociological research activities' ${ }^{13}$ Jakovljevic's core contribution to the humanities was his comprehensive examination of the concept of social pathology, in the course of which he combined psychiatric insights with anthropological, philosophical and sociological methodologies, aiming to explore alienation, mental distress and pathological maladjustment by identifying and addressing their social, economic and cultural roots and causes. ${ }^{14}$ Therefore, when discussing psychiatric illnesses he remained primarily interested in social relations, societal norms and cultural institutions predominant in the patient's social environment, and aimed to develop generalised definitions regarding the relationship between individual psychological malfunctioning and broader socio-economic and cultural conditions. ${ }^{15}$ His transcultural explorations served the same purpose and constituted an essential

\footnotetext{
7 See Ana Antic, Therapeutic Fascism: Experiencing the Violence of the Nazi New Order (Oxford: OUP, 2017), esp. chapter 2.

8 Jakovljevic, 'Prilog Proucavanju Sociopsihogeneze Neurotickih Poremecaja Licnosti', Sociologija, 2 (1959), 55.

9 On the relationship between Yugoslav psychoanalysis and the theory of workers' self-management, especially as it was discussed within the Praxis school, see Ana Antic, 'The Pedagogy of Workers' Self-Management: Terror, Therapy, and Reform Communism in Yugoslavia After the Tito-Stalin Split', Journal of Social History, 50, 1 (2016), 179-203.

10 Vladimir Jakovljevic, 'Predgovor', in Igor Caruso, Socijalni Aspekti Psihoanalize (Belgrade: Kultura, 1969).

11 Zagorka Pesic-Golubovic, 'Vladimir Jakovljevic (1925-1958)', 6-7. There, he maintained fruitful, if informal, professional relations with some of the leading members of the Praxis school of critical Marxist philosophy.

12 Jakovljevic, 'Prilog Proucavanju Neurotickih Poremecaja', 76.

13 Ibid., 59.

14 Jakovljevic, moreover, often published in non-medical anthropological, ethnographic and sociological journals, and relied on psychoanalytic and psychiatric insights to discuss mentalities, cultural habits and folk customs. See, for instance, Jakovljevic, 'Preziveli Oblici Orgijastickog Vidaarhaicnih Rusaliskih Obreda - Homoljske Rusalje, Padalice', Etnoloski pregled, 2 (1960), 7-23.

15 Zagorka Pesic-Golubovic, 'Vladimir Jakovljevic (1925-1958)', 6-7.
} 
part of his life-long research into socio-economic and cultural determinants of mental illness and health. ${ }^{16}$

In addition, as we will see below, Jakovljevic's Marxist orientation shaped his reading of Guinea's rapid modernisation and socio-economic development. While he agreed with most transcultural psychiatrists of his time that the forces of modernisation produced mental pathology in the decolonising world, his experiences of social revolution in Yugoslavia made him more optimistic regarding the Guinean population's ability to overcome psychological breakdowns, adapt to radical changes and achieve a more 'progressive' stage of development. As a researcher from a fellow socialist country, Jakovljevic remained more sensitive to Guinea's potentials for development and radical social change.

Jakovljevic first travelled to Guinea in March 1961, where he worked to establish the psychiatric services in a country which had previously had no mental health facilities other than one neurological department and one psychiatric centre in the main hospitals in the capital city, Conakry (as a rule, psychiatric patients in Guinea had been treated in general hospitals). He was thus engaged in organising the work of Guinea's fledgling mental health departments and in educating various types of psychiatric hospital staff. In addition to his work with psychiatric patients in the Donka and Baley hospitals in Conakry, Jakovljevic treated and interacted with mental health patients in prisons and asylums, as well as regularly visiting a variety of hospitals and private homes in the interior of the country. As a result, he obtained access to a diverse population of psychiatric patients, engaging with Guineans from various social, ethnic and cultural backgrounds as he travelled across the country. Alongside what appears to have been a very hectic schedule of clinical and organisational work, Jakovljevic remained interested in anthropological psychiatric research and collected epidemiological, sociological and ethnographic data, aiming to produce conclusive work in the fields of comparative and transcultural psychiatry. ${ }^{17}$

In the post-war era, Jakovljevic was among the very few Eastern Europeans to join the budding field of transcultural psychiatry, which was spearheaded by the Western psychiatric community and fundamentally tied to the process of decolonisation. For Yugoslavs, as well as for their Western colleagues, the rapidly decolonising African continent presented an unprecedented opportunity for exploration and experimentation, a research laboratory of sorts where the new, post-colonial international psychiatry might begin to be forged. ${ }^{18}$

\section{Transcultural Psychiatry: The Birth of a New Field}

In itself, transcultural (or cultural) psychiatry proved to be a complicated, contradictory discipline, which intersected in multiple and controversial ways with colonial mindsets, postcolonial realities and post-Second World War universalism and humanitarianism. Even though scholars have recently shed more light on the history of the discipline, its links to colonial psychiatry remain difficult to fully understand. Alice Bullard defined transcultural psychiatry as one of the multiple sets of practices into which colonial psychiatry transformed itself in the midtwentieth century: with the slow and agonising death of the West European colonial project, Western psychiatrists searched for more productive ways of thinking about traditional nonWestern concepts of mental health and healing strategies and sought to integrate non-European ideas of psychological abnormality and therapy into the dominant psychiatric science. ${ }^{19}$ On the

\footnotetext{
16 On the development and institutionalisation of Yugoslav psychiatry in the 1940s and 1950s, see Antic, Therapeutic Fascism.

17 Vladimir Jakovljevic, 'Transkulturno-psihijatrijska Proucavanja u Gvineji: Preliminarno Saopstenje', Neuropsihijatrija, 11, 1 (1963), 24-5.

18 Jakovljevic, 'Social Science in Medicine' (review), Sociologija, 2 (1959), 178-80.

19 Alice Bullard, 'Imperial Networks and Postcolonial Independence: The Transition From Colonial To Transcultural Psychiatry', in Sloan Mahone and Meghan Vaughan, eds., Psychiatry and Empire (London, UK: Palgrave MacMillan, 2007).
} 
one hand, as Emmanuel Delille has argued, the emergence and professionalisation of transcultural psychiatry as an academic discipline signified a period of radical transition, driven by the uncertainties and reassessments of the decolonisation period. ${ }^{20}$ At the same time, however, the discredited colonial background was difficult to shed: some of the continuities between colonial and transcultural psychiatry are striking, while several champions of late-colonial psychiatry became part of post-Second World War transcultural psychiatric circles. ${ }^{21}$ Early transcultural psychiatric scholarship tended to perceive the cultures of former colonies as self-contained, static entities and described them as exotic and archaic, reifying their forms of communication and core traits. In the 1960s and 1970s transcultural psychiatrists still understood 'cultures' as '“out there", residing entirely with the other, while professionals were assumed to base their work on a universal system of knowledge grounded in science that was viewed as acultural'. ${ }^{22}$ As a result, as Arthur Kleinman has pointed out, transcultural psychiatry tended to pay lip service to ethnographic and anthropological research, assuming that cultures merely determined the 'camouflage' of disease and at best shaped their symptoms and superficial expressions. ${ }^{23}$ Such medical universalism reinforced Eurocentric classification and treatment systems, disregarding a careful analysis of local cultural, social and economic contexts and working with simplified notions of non-European societies and values.

Jakovljevic aligned himself with international currents of transcultural psychiatric research, initially through studies comparing Macedonia and France, and later in explorations of the former French colony of Guinea in Western Africa. As France was one of the homelands of postSecond World War transcultural psychiatry, Jakovljevic's exposure to transcultural psychiatry during his studies in Paris had shaped his already existing interest in the socio-cultural determinants of mental illness and guided him towards the bourgeoning field of international postcolonial psychiatric research. Initially Jakovljevic took part in the WHO's initiatives in post-war international psychiatry as well as in the ambitious research projects emerging around the Canadian journal Transcultural Psychiatry, which was based at the McGill University's increasingly influential Division of Social and Transcultural Psychiatry. Such projects largely focused on gathering information regarding the frequency and symptoms of a variety of psychiatric disorders from around the world. ${ }^{24}$

In his thirty months of clinical and research work in Guinea Jakovljevic aimed to address some of the core questions and problems of transcultural psychiatry. Are there cultures in which mental disorders do not exist or are extremely rare? Are there epidemiological differences between cultures when it comes to mental illness? ${ }^{25}$ But beyond these questions typical of postSecond World War cultural psychiatry, Jakovljevic was also influenced by a long line of psychiatric and psychotherapeutic forays into anthropological and ethnographic research, which questioned whether a universal psychological (or psychoanalytic) self could be assumed and sought to ascertain to what extent it was bound by socio-cultural determinants. ${ }^{26}$

20 Emmanuel Delille, 'On the History of Cultural Psychiatry: Georges Devereux, Henri Ellenberger, and the Psychological Treatment of Native Americans in the 1950s, Transcultural Psychiatry, 53, 3 (2016), 393.

21 For particularly critical assessments of ethnopsychiatry in France, see Didier Fassin, 'Ethnopsychiatry and the Postcolonial Encounter: A French Psychopolitics of Otherness', in Warwick Anderson, Deborah Jenson and Richard Keller, eds., Unconscious Dominions: Psychoanalysis, Colonial Trauma, and Global Sovereignties (Duke University Press, 2011).

22 Laurence J. Kirmayer, '50 Years of Transcultural Psychiatry', Transcultural Psychiatry, 50, 1, (2013), 3-5.

23 Arthur Kleinman, 'Depression, Somatization and the "New Cross-cultural Psychiatry"', Social Science and Medicine, 11 (1977).

24 See, for instance, H. B. M. Murphy et al., 'Crosscultural Inquiry Into the Symptomatology of Depression: A Preliminary Report', Transcultural Psychiatry, 1 (Apr. 1964), 5-18; ibid. 'A Crosscultural Survey of Schizophrenic Symptomatology', International Journal of Social Psychiatry, 9, 4 (1963), 237-49.

25 Jakovljevic, 'Kulturna sredina i neuroze', Medicinski Glasnik, 50, 2-2a (1959).

26 See Jonathan Sadowsky, Imperial Bedlam: Institutions of Madness in Colonial Nigeria (University of California, 1993); Ashis Nandy, Savage Freud and Other Essays (Princeton: Princeton University Press, 1995); Stephen Frosh, For and Against Psychoanalysis (Abingdon: Routledge, 2006); Littlewood, Maurice Littlewood and Roland Lipsedge, Aliens and 
This then was an ambitious and comprehensive project of exploring the role of socio-cultural factors in the onset and understanding of mental illness. In it Jakovljevic relied on a variety of scientific and political influences to which he was exposed in order to move beyond the simplistic binaries of complete relativism, on the one hand, and (what he termed) Western 'ethnocentric' universalism, on the other, in evaluating mental normality. This position stood in implicit contrast to psychoanalytic anthropological research such as Geza Roheim's famous interwar explorations of Australian Aborigines, which argued for a universal, global concept of the unconscious. $^{27}$ Jakovljevic opined that socio-anthropological research in psychiatry should encourage the profession to revise all those theories of pathogenesis which assume 'a universally identical psychogenic content'. ${ }^{28}$ Such 'idealist speculation' divorced from careful engagement with social and historical conditions clashed with Jakovljevic's Marxist approach, which led him to focus much more carefully and systematically than most of his fellow transcultural psychiatrists on the role of socio-economic and cultural factors in shaping the psychological world of his patients.

As an alternative to relativism or universalism Jakovljevic proposed what he termed 'culturalintegrationism', or 'integrationist universalism'. Rather than descending into extreme cultural relativism or Western-centric universalism, Jakovljevic proposed that 'it [was] necessary, on the contrary, to study common principles, by synthetically generalising their specific expressions in a particular socio-cultural environment. ${ }^{29}$ Such common principles should then be built into the foundations of the new field of international psychiatry. This approach recognised the overwhelming importance of specific socio-cultural factors in causing psychiatric disorders in a given social setting. It required a careful assessment of both patients' and therapists' socio-cultural backgrounds and relied on comparative epidemiological and phenomenological analyses to identify those notions in mental pathology, therapy and prophylaxis which might be shared among cultures and civilisations. ${ }^{30}$ It was globe-trotting researchers such as Jakovljevic himself who offered to resolve the existing tension between 'ethnocentrism and relativism in psychiatric diagnostics'. ${ }^{31}$

In his clinical applications of the cultural-integrationist approach, Jakovljevic relied on interpreters to communicate with most of his native patients. Recruited from among local auxiliary medical staff as well as those studying to become psychiatric social workers, these interpreters also helped Jakovljevic develop what he called the 'socio-psychiatric' component of patient reports - a detailed exploration of every patient's sociological and environmental surroundings developed through specific questionnaires as well as lengthy interviews with family members and carers. According to Jakovljevic's descriptions, the translators were able to provide a more comprehensive socio-cultural interpretation of patients' behaviour and attitudes in addition to the basic linguistic translation of patients' statements. Helpfully, Jakovljevic's medically trained interpreters could situate patients' reactions and symptoms in a broader Guinean context and evaluate whether those reactions truly deviated from the Guinean 'norm'. This reflected Jakovljevic's insistence on relativistic socio-cultural criteria of normality and abnormality: by consulting his translators in this way, for example, he claimed that he 'avoided any possibility of Euro-American centralism, as well as anarchical relativism'. ${ }^{32}$

Alienists: Ethnic Minorities and Psychiatry (Abingdon: Routledge, 1997); Ranjana Khanna, Dark Continents: Psychoanalysis and Colonialism (Durham: Duke University Press, 2003).

27 Joy Damousi, 'Geza Roheim and the Australian Aborigine: Psychoanalytic Anthropology During the Inter-War Years', in Anderson et al., Unconscious Dominions, 75-95.

28 Jakovljevic, 'Kulturna Sredina i Neuroze', 50-3.

29 Jakovljevic, 'Transkulturno-psihijatrijska Proucavanja u Gvineji', in Prilozi za Socijalnu Patologiju (Belgrade: Sloboda, 1984), 134.

30 Ibid., 170.

31 Jakovljevic, 'Kulturna Sredina i Neuroze', 52.

32 Jakovljevic, Prilozi za Socijalnu Patologiju, 130-3. 
Still, in his concern to move away from such 'anarchical relativism', Jakovljevic consistently applied the American Psychiatric Association's classification of illnesses and ultimately translated all psychiatric disorders which he encountered in Guinea into 'universal' medical diagnoses developed in the United States - for all his interest in detailed anthropological research and socio-cultural particularities, his Guinean patients, just like his Yugoslav and French patients, were diagnosed with schizophrenia, mania, different forms of neurosis, reactive psychosis and a variety of psychosomatic and sociopathic disorders. ${ }^{33}$ According to Jakovljevic, 'there existed certain specific manifestation of individual mental disorders, which could be classified within the traditional schemes [only] with some difficulty'. Nonetheless, he concluded that such specificities did not warrant the creation of novel diagnostic categories, as 'in essence [they] belonged to the already existing nosological groups'. ${ }^{34}$ Therefore, Jakovljevic's own conclusions about mental illness patterns in Guinea had important universalist aspects, and his Marxism did not lead him to question Eurocentric nosologies. But, as we will see below, his universalism was further informed by a sense of socialist solidarity between Eastern Europe and the global South, and by his belief that all societies can be evaluated as progressive or otherwise according to the universal Marxist standards of historical development. ${ }^{35}$ This set him apart from most of his Western European colleagues.

\section{Eastern Europe and Guinea}

In 1958 Guinea was the only French territory to opt for immediate independence in the September constitutional referendum. All the other parts decided to remain junior partners in a newly formed French Community, defined in the Fifth Republic's recently passed constitution, and accepted the continuation of French tutelage for an indefinite period of time. However, the Guineans were urged by their national branch of the African Democratic Assembly (Rassemblement Démocratique Africain; RDA), an inter-territorial association of political parties in French West Africa and one of the most powerful political forces in the region, to choose a more radical and disruptive path of fully independent statehood and socialist transformation. ${ }^{36}$ The reasons behind this were many and mainly had to do with the unusually successful national mobilisation strategies of the country's dominant political party and its close links with the broadest sections of its membership. The national RDA, which was to rule Guinea in the coming four decades, was an organisation openly styled after the Communist Party of France, and by 1958 it grew to be largely shaped by its grassroots militant left-wing factions - trade unionists, radical students and youth and women's associations. ${ }^{37}$ These resolutely pushed the political leadership towards the left in the months leading up to the 1958 referendum and radicalised the RDA's vision of postcolonial revolutionary politics. This was a startling and potentially promising beginning to Guinea's decolonisation, and the country soon embarked on an

33 Ibid., 124.

34 Ibid., 134.

35 This was perhaps more akin to the early universalist trends in African transcultural psychiatry, such as the school of thought championed by Nigeria's Thomas A. Lambo, who promoted the notion of the 'unity of mankind' when it came to patterns of mental health and disease because he believed that such a platform would help fight racism in European psychiatry. Michael Heaton, Black Skin, White Coats: Nigerian Psychiatrists, Decolonization and the Globalization of Psychiatry (Athens: Ohio University Press, 2014).

36 Elizabeth Schmidt, 'Anticolonial Nationalism in French West Africa: What Made Guinea Unique?', African Studies Review, 52, 2 (2009), 1-34

37 Elizabeth Schmidt, 'Cold War in Guinea: The RDA and the Struggle Over Communism, 1950-1958', Journal of African History, 48, 1 (2007), 95-121; see also Elizabeth Schmidt, Mobilizing the Masses: Gender, Ethnicity and Class in the Nationalist Movement in Guinea, 1939-1958 (New Hampshire: Heinemann, 2005) and Schmidt, Cold War and Decolonization in Guinea, 1946-1958 (Athens: Ohio University Press, 2007); Claude Riviere, Guinea: The Mobilization of a People (New York: Ithaca, 1977); Tony Chafer, The End of Empire in French West Africa: France's Successful Decolonization? (London: Bloomsbury, 2002). 
exceptionally ambitious programme of modern nation building and social, cultural and political transformation, allying itself with Soviet, then Chinese communism.

But this auspicious start was ultimately not indicative of the overall success of the national revolution. Guinea's decisive bid for socialism entailed not only a distancing from the French colonial education and ideological value systems but also an assault on what the leadership termed 'primitive' cultural and religious traditions, the controversial 'demystification campaign'. In their attempt to culturally and socially 'rehabilitate' the nation, the Guinean post-colonial leadership aimed to counter 'the intellectual elitism and Eurocentrism bred by colonial schooling' and raise a new generation of nationalist youth by thoroughly transforming their 'historical consciousness, cultural sensibilities, and future aspirations'. ${ }^{38}$ This far-reaching concept of reform, modernisation and revolutionisation of mentalities understandably 'triggered multiple, multifaceted disruptions of local life everywhere in Guinea'. ${ }^{39}$ Moreover, the enormous disruption was soon accompanied by growing authoritarianism of an increasingly brutal and intolerant RDA regime, whose charismatic leader Ahmed Sékou Touré clamped down on his opponents from the early 1960s on, declaring the beginning of a 'Socialist Cultural Revolution' in 1968 and remaining the uncontested leader of the country until his death in 1984.

For many commentators Guinea's attempted revolution was a prime example of a failed decolonisation, the democratic potential of the late 1950s apparently squandered in the subsequent decades of dictatorship, violence and political and ethnic strife. ${ }^{40}$ Despite this, the radical reforms of the 1960s and 1970s thoroughly transformed the face of Guinean society, and this sweeping change made the country seem like a dynamic laboratory for revolutionary policies and designs. Guinea's experiences of modernisation, urbanisation and dismantling of the old sociocultural structures might well have resonated with those of experts arriving from Eastern Europe's newly socialist republics. Guinea itself was also attracted to the promise of East European socialist revolutions and developed extensive educational and technical exchanges with the Eastern Bloc in the 1960s. As Mike McGovern has argued, socialist states in Africa often 'had more concrete political and economic links to the socialist countries of Europe and Asia than to some of their neighbours on the African continent'. ${ }^{41}$ Yugoslavia's path of non-alignment proved additionally attractive to newly sovereign African states, which hoped to avoid falling under the hegemony of either side in the Cold War. Signifying the importance of Yugoslavia in particular, the face of Josip Broz Tito featured on Guinea's 10,000 sily note. ${ }^{42}$

From Jakovljevic's Eastern European perspective, the decolonising world was of notable interest as well. The rapid socio-economic, political and cultural changes involved in both the socialist revolution and post-colonial modern state-building featured very importantly as pathogenic factors in his interpretations. Even though Jakovljevic never explicitly equated Yugoslavia and Guinea, his descriptions of Macedonia's 'primitiveness' corresponded very closely to his analyses of Guinea's core social problems. In that sense Jakovljevic's texts (unintentionally) indicated that, despite its 'Europeanness', Yugoslavia might be eminently comparable to the decolonising world. It is this unspoken similarity between Eastern Europe and Guinea - which leaps off the pages of Jakovljevic's writings - that the article is now going to explore.

Before his long-standing engagement with Guinea Jakovljevic conducted psychiatric epidemiological and sociological research in Macedonia and made comparisons with the mental health situation in Paris. Aiming to apply ethnopsychiatric methodology and theoretical frameworks to

\footnotetext{
38 Jay Straker, Youth, Nationalism and the Guinean Revolution (Bloomington and Indianapolis: Indiana University Press, 2009), 11.

39 Ibid., 12.

40 David Rieff, 'In Defense of Afro-pessimism', World Policy Journal, 15, 4 (1998-1999), 10-22; Patrick Chabal and JeanPascal Daloz, Africa Works: Disorder as Political Instrument (Oxford and Bloomington: James Currey and Indiana University Press, 1999); Manthia Diawara, In Search of Africa (Cambridge: Harvard University Press, 1998).

41 Mike McGovern, Unmasking the State: Making Guinea Modern (Chicago: University of Chicago Press, 2012 ), 160.

42 Ibid., 161.
} 
the study of the pathogenesis of neuroses, Jakovljevic used the research material he collected during his employment in Macedonia: in 1953-4 alone, for instance, he interviewed over 1,500 neurotic patients at the Skopje neuropsychiatric hospital and compared the results and statistical information with those he compiled in psychiatric clinics and consulting rooms in Paris in 1956 and $1957 .^{43}$

In his writings on Macedonia Jakovljevic regularly set it up against 'civilised countries', noting that the rate of neurotic disorders was much lower in Macedonia - a standard trope of colonial psychiatry which insisted that psychological disease such as neurosis or schizophrenia was a unique characteristic of highly industrialised, urbanised and cultured regions of the world. But Macedonia was also undergoing dramatic transformations, which meant that its rate of psychiatric morbidity was alarmingly on the rise. Focusing on the 'primitive' and 'underdeveloped' regions of Yugoslavia, Jakovljevic delineated the core socio-psychological characteristics of this 'primitive mentality:' 'totemistic beliefs and appropriate rituals all the way to exorcism; . . . extreme patriarchy in families; open aggression in the form of blood vengeance; buying of women who are evaluated as merchandise', and a 'marked submissiveness of women', etc. Moreover, Macedonia was reportedly characterised by 'extremely archaic' social structures, which exhibited 'exceptional forms of socio-psychological backwardness'; ${ }^{44}$ this resulted in an 'exceptionally levelled collective psyche' that defied and precluded the process individuation or the formation of richer forms of internal life. ${ }^{45}$ Especially among the Muslim population, psychiatric research identified further symptoms of severe underdevelopment: 'extreme fatalism and even more developed primitive beliefs', 'propensity to sexual deviations', a 'great rigidity of personalities', as well as a tendency to assign mystical causality to a long list of life events and to resort to magic acts, protective amulets or 'bizarre medications of archaic or religious origin'. ${ }^{46}$

Jakovljevic's descriptions of cultural, ethnographic and anthropological aspects of postcolonial Guinean society relied on the same set of terms and concepts: in the African country's primary and secondary social institutions, Jakovljevic identified a similar combination of 'primitivism', 'hierarchy', 'patriarchy' and 'archaic' relations, and he particularly emphasised the remarkably unequal position of women and youth in traditional settings. Just as in the south of the Balkans, he wrote, most Guineans' 'life is still full of magical rituals, with an almost universal application of magic for the purposes of attack and defence'. Moreover, in Guinea 'one believes that the world constitutes a certain vitalistic unity, inhabited by a variety of supernatural and natural creatures'; the 'fatalistic actions' of these beings explain the course of all events and history. ${ }^{47}$ For these reasons, prayers, sacrificial rituals, amulets and invocations of magical powers appeared to be the core strategies for surviving life's calamities.

However, the largest number of socially conditioned psychological disorders stemmed from a 'dynamic process of abrupt changes of one social environment' - a condition equally applicable, as it transpired, to Macedonia/Yugoslavia and Guinea/the decolonising world. In the more developed parts of Macedonia, a 'patriarchal-oriental' lifestyle and mentality gradually became entangled with more modern, Western European influences, and this profoundly reshaped the collective psyche of the region. The process of change which triggered the largest proportion of psychiatric disorders had to do with industrialisation, modernisation and urbanisation, as well as the implementation of some of the core principles of the socialist revolution, such as workers' rights and gender equality. In all these respects Macedonia emerged as surprisingly akin to Guinea and other sub-Saharan African countries, despite their dramatically different historical,

43 Jakovljevic, 'Doprinos Proucavanju Uloge Psiholoskih Uticaja Sociokulturne Sredine u Patogenezi Neuroza', Neuropsihijatrija, 7, 1-2 (1959), 41-2.

44 Jakovljevic, 'Prilog Proucavanju Neurotickih Poremecaja', 62-3.

45 Jakovljevic, 'Doprinos Proucavanju Uloge Psiholoskih Uticaja Socio-kulturne Sredine u Patogenezi Neuroza', 42.

46 Jakovljevic, 'Utjecaj Kulturno-socijalne Sredine na Psihopatiku Sizofrenih Stanja', Neuropsihijatrija, 5, 2 (1957), 143.

47 Jakovljevic, 'Transkulturno-psihijatrijska Proucavanja u Gvineji: Preliminarno Saopstenje', Neuropsihijatrija, 11, 1 (1963), 24. 
political and cultural contexts. In the Macedonian case, this process denoted 'a change of lifestyle from simple and primitive . . to to complex and cultured; . . . a change of belief system from a mystic-causal to a rational-causal type', as well as a move towards more abstract thinking and linguistic structures and radical transformations of large, 'backward' and highly hierarchical families. ${ }^{48}$ In 1960s Guinea, similarly, the dramatic transformations of the post-colonial era were primarily marked by 'a completely serious cultural emancipation, which is implemented both through education and through political propaganda', as well as by 'mechanisation, industrialisation and socialisation [implementation of certain socialist organisational principles], which results in the sudden migration to cities and change in occupations and lifestyles'. ${ }^{49}$ The 'rural exodus' plagued the collective mental health of Guineans, but it was a price that needed to be paid for social, cultural, economic and political progress. In the African context the most common social conflicts reportedly concerned gender and age divisions, as 'women and youth were in the process of obtaining an increasing list of legal rights, which men and the elders did not want to grant them without resistance, ${ }^{50}$

Moreover, by far the harshest and most universal forms of interpersonal conflict Jakovljevic observed were between those 'faithful to the traditional norms and those willing to abandon them'. But the very process of 'civilisation' was troubled and uneven, so that 'the new was permanently pregnant with the old', and those who started undergoing modernisation or 'Westernisation' were often quite torn between different aspects of their personality: a civilised person would be rather polarised in all their activities - 'superficially Westernised but intimately traditional, superficially rational but intimately irrational, superficially controlled but fundamentally impulsive'. ${ }^{51}$ According to Jakovljevic, 'new layers of Western culture [were] successfully grafted onto these primitive layers, so that in the cities they usually co-exist[ed] or [were] indeed deeply interrelated, and only [got] separated in illness'. ${ }^{52}$ Such polarisation led to a large number of psychological breakdowns whose roots were in this bifurcated 'pseudo-European' and African existence, the result of forcing ancient systems into novel, modernised conditions. In fact, in his recent anthropological study of the Demystification programme, McGovern has argued, along similar lines, that the most violent aspects of the Guinean state's assault on polytheistic religious traditions signalled a pervasive 'modernist anxiety' and the modernisers' deep-seated psychological need to 'purge' the lingering backwardness and primitivism from themselves. This fundamental uncertainty about the nation's ability to become and remain modern, according to McGovern, drove Sékou Touré's brutal campaign to 'eradicate the embarrassing residue of premodern backwardness from the body politic'. ${ }^{53}$ Jakovljevic could, of course, recognise such problems and complications in his own rapidly modernising home country.

However, such comparisons or parallels were never stated in an explicit manner. But the language which Jakovljevic used to describe the cultural and psychiatric situation in both Macedonia and Guinea/African countries in general was extremely similar and betrayed a set of assumptions which Jakovljevic might have been hard pressed to fully support openly. Throughout his comparative studies, he tended to reiterate that 'European cultures' - including Yugoslavia and France as his clinical case studies - presented a very different 'configuration/ layout of structure of specific mental disorders'; moreover, Yugoslavia in particular had a much higher frequency of mental disorders than Guinea or Africa as a whole, which placed her firmly in the camp of developed, Western countries (such as, for instance, the United States or United Kingdom) ${ }^{54}$ As he claimed in his comparative study of neuroses, both Macedonia and France

\footnotetext{
48 Ibid., 75.

49 Jakovljevic, Prilozi za Socijalnu Patologiju, 106.

50 Ibid., 121.

51 Ibid., 176.

52 Ibid., 24-5.

53 McGovern, Unmasking the State, 20.

54 Ibid., 177.
} 
'originated from the same archaic family' and had experienced similar historical events and influences, which explained a basic similarity and comparability of certain formative social institutions. At the same time, however, even though Yugoslavia was not an 'archaic' society such as, say, Guinea, its specific historical development still set it radically apart from the French case, producing very dissimilar forms of cultural identity and secondary social institutions. ${ }^{55}$ This constantly shifting political and cultural image of the author's home country was in fact quite telling of the complex position Yugoslavia inhabited on the international scene: its political alliances were as complex as its (apparent) psychiatric identity, and it was at different times comparable to a variety of very different states and cultures, from Africa, to Central and Western Europe.

\section{Colonial Psychiatry and its Legacies}

This confusing state of affairs was further complicated by Jakovljevic's tendency to quote and ally himself with both Western colonial psychiatrists such as John Colin Carothers and prominent anti-colonial and post-colonial psychiatric experts such as Lambo. This was in large measure a product of the complex and intellectual incoherent nature of transcultural psychiatry as a field: these internal tensions marked the development of post-Second World War global psychiatric clinical and research practice, and they are of central importance to understanding Jakovljevic's own contradictory conclusions and intellectual legacies. In that sense, Jakovljevic's perception of Guinea's position on the international scale of civilisations was extremely ambiguous: while he emphasised the relevance of African research for understanding the effects of dramatic social shifts in Eastern Europe, he also accepted, relatively uncritically, an openly colonial binary of civilised Europe versus primitive Africa. In this latter constellation, the Yugoslav lands, despite their socialist reorientation, belonged firmly to the European family of nations and cultures, which was reportedly characterised by a significantly different structure and phenomenology of mental illness.

This was a longstanding phenomenon: from well before the Second World War Yugoslav psychiatrists for the most part adopted the terminology of Western colonial psychiatry in the domestic context and regularly referred to local mental health patients as 'primitive' and 'uncivilised'. The growing literature on the history of colonial psychiatry thus might be useful for illuminating the nature of the relationship between psychiatrists and their patients of very different social and educational backgrounds in the Yugoslav context. The historiography of colonial psychiatry described the complex and potentially explosive encounters between the West European psychiatric elite, with their modernising and 'civilising' agendas, and local patients, who challenged the tropes and classificatory systems of European medicine and brought with them a set of traditional beliefs and explanations. Such a clash of paradigms turned clinics into sites of fierce contestation: 'psychiatrists and patients engaged in a protracted argument about incompatible approaches to illness' ${ }^{56}$ According to Richard Keller's description of the French Algiers school of psychiatry, the psychiatrists were regularly baffled by patients who presented 'diffuse complaints' and were 'unable to translate their experience of illness into a comprehensible symptomatology. 57 This description is reminiscent of the attitudes and diagnostic behavior of Yugoslav psychiatrists, who, while sharing a cultural and ethnic background as well as a native language with their patients, were prone to pathologise ineloquence and unfamiliarity with medical paradigms. Moreover, colonial patients often understood their own mental anguish in the context of traditional and magic beliefs, while their psychiatrists tended to treat the allegiance to such notions as a symptom of pathological mental deterioration; in a similar vein, the lack of

\footnotetext{
55 Jakovljevic, 'Doprinos Proucavanju Uloge Psiholoskih Uticaja Socio-kulturne Sredine u Patogenezi Neuroza', 51.

56 Richard Keller, Colonial Madness: Psychiatry in French North Africa (Chicago: University of Chicago Press, 2007$), 87$.

57 Ibid., 110.
} 
education, literacy or Western hygienic habits tended to mark entire societies as more likely to develop forms of insanity in the European psychiatrists' worldview.

In this sense, commonalities with the Yugoslav case are striking and instructive, and they might be explained by reference to a civilising mission of sorts which the Western-educated Yugoslav psychiatrists shared with their colonial counterparts in the first half of the twentieth century. Working in a slowly (and painfully) modernising yet predominantly agricultural country, interwar Yugoslav mental health professionals entertained glorious ideas of their important social and political role. Keller's note that, in their own minds, 'colonial psychiatrists occupied the front lines in a struggle between Western biomedicine and what they considered to be superstitious tradition', ${ }^{58}$ could be applied to the Yugoslav psychiatric profession with very little qualification. In fact, Yugoslav medical practitioners as a whole seemed to wage an all-out war against the rural population's conceptions of health, illness and hygiene. ${ }^{59}$ Yugoslav psychiatrists, trained in Western Europe and deeply involved in broader European professional networks, thus likely had more in common with French or German doctors than with their illiterate peasant patients. ${ }^{60}$

Some of that intellectual affiliation certainly survived the revolution of 1945, and the literature produced by West European colonial psychiatrists formed a very important part of Jakovljevic's own bibliography. Within the context of Yugoslavia's own project of socialist modernisation and urbanisation there was no dramatic change in psychiatrists' conceptions of their 'civilising mission' in a largely under-educated and rural country. In fact, under socialism the task of turning the existing population into a collective of much more progressive, modernised, forwardlooking Marxist citizens was more pressing than ever, and Jakovljevic and his colleagues constantly referred to the prominent role of psychiatrists in effecting these major social, cultural and psychological changes. As Jakovljevic noted in relation to the rapid socialist transformation of Yugoslav families, the transition from 'primitive', more diffuse type of families to much narrower, nuclear families characteristic of 'civilised societies' was at the core of the social changes of the post-war period, and the psychiatric profession had a foremost duty to alleviate the psychological toll of this dramatic move. ${ }^{61}$ In that sense, Yugoslav psychiatrists could be both colonial-minded and extremely critical of colonial legacies, and this became particularly pronounced when they actually travelled to and engaged with the former colonies.

In the context of socialist societies in Eastern Europe, moreover, the idea of modernising and civilising backward cultures and peoples was not uncommon. As Bruce Grant noted in connection with the Soviet political attitude towards the indigenous populations of Siberia, the political project of building communism and communist consciousness in the entire country inevitably entailed the speeding up of the cultural development of those peoples who were not advanced enough on the Marxist historical scale. For the Soviet authorities and ideologies this meant that the core goal of socialist development was to quickly move these people and areas from 'tradition' to 'modernity', to accomplish a 'heroic leap from primitive-communal society to

58 Ibid., 119.

59 In the countryside as well as in recently urbanised areas, moreover, fortune-tellers emerged as the psychiatric profession's rivals of sorts for popular attention and trust. They offered alternative, supernatural interpretations of psychological malaise, provided specific advice for resolving mental problems and even served as a particular kind of psychotherapists, in the context in which no psychotherapy was practiced in hospitals. Consequently, since the late nineteenth century, the state attempted to eliminate or at least restrict and control their practice, but those efforts proved largely unsuccessful.

${ }^{60}$ Foreign visitors to Yugoslavia and Belgrade in the 1920s and 1930s regularly noted particularly strong conflicts and contradictions between traditional and modern (Western) forms of life, the extreme conservatism and poverty of the countryside which clashed with internationalist currents and Westernised mass culture of large cities, so that 'East and West created a specific mix, and one felt with certainty the existence of a gap.... There is nothing that could bridge it, and one is constantly afraid of suddenly falling into a hole'. (Marie-Janine Calic, Sozialgeschichte Serbiens 1815-1941: Der Aufhaltsame Fortschritt wahrend der Industrialisierung (Munich: R. Oldenbourg Verlag, 1994), 120. Psychiatric hospitals well represented the nature and implications of this 'unbridgeable' gap.

61 Vladimir Jakovljevic, Neuravnotezena porodica (Belgrade: Centar za obavestavanje roditelja, 1961), 4. 
socialism'. ${ }^{62}$ At the same time, however, Grant argues, the dominant perception of the Siberian peoples in Russian consciousness remained largely unchanged: they were primitive, 'untamed' and wild unintegrated in the broader Soviet society despite the state's monumental effort. In the final analysis the socialist state's extreme paternalism likely aided the persistence of that image of backwardness and primitivism. In the African context as well, 'scientific socialism . . . insisted upon a single path to modernity. Although socialism identified problems of exploitation within European modernity, it did not hesitate to treat non-European societies with Eurocentric disdain'. ${ }^{63}$ The Marxist and Western colonial ideas of the 'primitive' thus coexisted and overlapped in the socialist world, and East European medical doctors' perception of their own domestic patient populations as primitive or unmodern shaped their understanding of both the decolonising world and Western colonial medical/psychiatric discourses.

\section{The Problem of a 'Primitive' Patient}

In his article published in a Yugoslav medical journal following a conference presentation in Sarajevo, Jakovljevic's Israeli colleague and collaborator G. R. Tamarin focused on the complications that psychiatrists and psychotherapists faced when dealing with uneducated, 'backward' and mentally 'undifferentiated' patients whose possibilities for self-reflection were limited. His article emphasised the multiple meanings of the word 'primitive': it could refer to those socioeconomic strata considered uncultured in a European or Israeli setting, as well as to those with 'pre-logical' and 'fantastic' thought patterns hailing from the tribal depths of black Africa. Tamarin drew attention to the possible links between these two meanings. He was primarily concerned with the former group, with whom he regularly engaged in his daily clinical practice. These were Israeli patients with little education and no 'broader interests or ambitions', who struggled to get involved in any meaningful therapeutic interpersonal dialogue. ${ }^{64}$ But this linguistic confusion regarding the exact connotation of the concept of 'primitivism' would become particularly important for people like Jakovljevic, who tended to move between the two meanings of the word without reflecting on the transition. In psychiatric discussions 'primitive' mentalities of European (or Israeli) populations were often associated with civilisational 'primitivism' of the non-European world, and this implicit connection affected Jakovljevic's engagement with both domestic and global concerns.

Tamarin's language was unusually harsh and dismissive of the socially underprivileged; however, his Yugoslav colleagues could likely identify with the general problem he discussed. At the core of this dilemma was the very idea of progress and modernisation: many psychiatrists' stance towards the majority of their patients tended to be rather ambivalent, as their 'primitivism' and 'backwardness' apparently complicated the application and ultimate success of analytic interpretive therapeutic frameworks. At the same time, the psychiatric profession considered the modernisation and civilisation of the 'backward' masses to be among its main tasks and its core political leverage, especially in the context of post-war revolutionary changes in Eastern Europe. The question of whether and under what circumstances such primitivism could be overcome informed the majority of post-war professional debates in Yugoslavia. ${ }^{65}$

62 Bruce Grant, 'Siberia Hot and Cold: Reconstructing the Image of Siberian Indigenous Peoples', in Galya Diment and Yuri Slezkine, eds., Between Heaven and Hell: The Myth of Siberia in Russian Culture (New York: St. Martin's Press, 1992), 227-8.

63 Mcgovern, Unmasking the State, 19.

${ }^{64}$ G.R. Tamarin, 'Primitivna Licnost i Mentalna Higijena', Medicinski Glasnik, 50, 2-2a (1959), 55-6.

65 Vladislav Klajn, 'Problem Rehabilitacije - Rehabilitacija Neuroticara', VSP, 7, 8 (1958), 529-31; Klajn, Petar, Razvoj Psihoanalize $u$ Srbiji,78-83. In the 1960s and 1970s Yugoslav mental health professionals debated ways to practice psychoanalysis and psychotherapy when faced with a large number of 'unsophisticated' and 'uneducated' patients. In the course of these discussions they devised eclectic psychodynamic approaches which conceptualised the therapist himself as an instructor, a tutor who directed his predominantly 'primitive' patients in a firm, disciplined, at times heavy-handed 
The issue of social and cultural 'primitivism', and its effects on psychiatric practice, thus loomed large on the minds of Jakovljevic and his colleagues, and this domestic concern crucially affected Jakovljevic's own explorations of a different (but not too different) kind of 'backwardness' in Guinea. Still, in Jakovljevic's own worldview, the terms did get redefined to a significant extent. Unlike in the pre-war psychiatric jargon, the concept of primitivism employed by post-war socialist psychiatry was imbued with expectations of progress and the overcoming of backwardness. At the same time, Paris - Jakovljevic's symbol for civilisation and cultural sophistication - demonstrated clear signs of degeneration and decay, so that the very terms 'primitivism' and 'civilisation' assumed somewhat altered meanings. As Jakovljevic concluded, Macedonia constituted a simpler environment 'which was radically advancing' and which had a predominantly negative attitude towards complex neurosis. On the other hand, France, an incomparably more complex social and cultural setting 'which was in the process of destructuring', tended to have a peculiar appreciation for neuroticism, so that a patient 'could easily achieve a certain provisory, abnormal balance, not attacked by his social milieu'. ${ }^{66}$

As discussed above, while modernisation necessarily carried with it a sharp increase in psychological suffering and disorder, it was not a failed mission: even 'primitive' African inhabitants could adapt to a more technically and culturally advanced surrounding. The pessimism and biological determinism of the pre-socialist years were gone, and the new trends and assumptions in Jakovljevic's rendering of transcultural psychiatry predicted ultimately positive outcomes of the momentous social and political transformations of both sub-Saharan Africa and the socialist bloc. Writing of Guinea's ever fluctuating social makeup, he observed that it became clear that inherited philogenetic cultural models do not necessarily repeat themselves in the course of development, but are always learnt and, in the course of that learning, can always be changed'. ${ }^{67}$ This clearly boded well for the Yugoslav socialist development too, and perhaps even echoed Yugoslav psychiatrists' experiences with 'partisan hysteria', when 'primitive' peasant soldiers underwent temporary bouts of neurosis following the end of the war but were then successfully integrated in a modernising socialist society. ${ }^{68}$

Since cultural patterns and dispositions were so malleable and dependent on socio-cultural environment and political and economic structures, Jakovljevic could not draw a straightforward line between 'primitive' civilisations and the 'childhood stage of humanity' - a common trope not only in twentieth-century Western psychiatry, but also in more progressive psychoanalytic and anthropological discourses, which saw the 'savages' of the non-white world as fascinating snapshots of humanity as it was before the onset of 'civilisation'. As Freud's close associate and biographer Ernest Jones noted, 'it is possible that the conscious thinking of savages is more directly and extensively influenced by unconscious factors than is that of civilised people, just as is so with the child' ${ }^{69}$ In contrast, Jakovljevic criticised what he termed the 'infantilism thesis'. Even though Jakovljevic admitted that 'primitive adults' of Guinea shared certain mental traits with children from the civilised world, differences were equally if not more important. ${ }^{70}$ Marxist psychiatry and psychoanalysis - although it assumed that progress was unidirectional and that Guinea had to 'catch up' - could hardly view African civilisations in a static manner within the evolutionary context, but instead argued that cultures and societies could, under propitious circumstances, make revolutionary leaps in their own development and progress: 'our

\footnotetext{
manner, and who dispensed advice and guidance much more straightforwardly than an orthodox psychoanalyst would have. Vladislav Klajn, Jakovljevic's supervisor at the 'Dragisa Misovic' hospital, spearheaded these debates, which originated in the hospital's neuropsychiatric ward.

66 Jakovljevic, 'Prilog Proucavanju Neurotickih Poremecaja', 80-1.

67 Jakovljevic, Prilozi za Socijalnu Patologiju, 167.

68 See Ana Antic, 'Heroes and Hysterics: "Partisan Hysteria” and Communist State-building in Yugoslavia after 1945', Social History of Medicine, 27, 2 (2014), 349-71.

69 Quoted in Joy Damousi, ‘Geza Roheim'.

70 Jakovljevic, Prilozi za Socijalnu Patologiju, 142.
} 
experiences have clearly demonstrated that a primitive personality, who is young and capable enough, can successfully integrate in a technically and culturally developed environment, even though that integration might be accompanied by temporary mental disorders' ${ }^{71}$ In that sense, despite being heavily influenced by Western European psychoanalytic thinking, Jakovljevic distanced himself from those transcultural psychoanalytic and psychiatric discourses which saw the 'contemporary "primitive" as a version of the early stages of human society' who could consequently have no history. ${ }^{72}$

In the same vein, Jakovljevic complicated the standard narrative regarding psychiatric epidemiologies in the non-Western world. On the one hand, he subscribed to the thesis that the overall frequency of mental disorders was lower in Guinea than in the 'civilised' world Jakovljevic's statistics on Guinea's psychiatric morbidity broadly corresponded to the figures Carothers identified in Kenya. ${ }^{73}$ However, he still insisted that 'even underdeveloped countries could see relatively high numbers of mental disturbances' and that 'there existed highly complex psychopathologies even among the most backward sections of the [Guinean] population' ${ }^{74}$ British imperial psychiatrists and psychoanalysts often assumed that lower rates of mental illness meant that 'Africans and Asians were incapable of examining their feelings' or did not have 'a distinct personality', but instead '[shared] a communal mind attuned to the elementary collective consciousness of his tribe. ${ }^{75}$ However, Jakovljevic concluded that it was not the assumed inherent and unchangeable simplicity of the mind that predetermined the status of mental health or illness in the African world; it was a complex web of social, political and cultural circumstances. ${ }^{76}$ In fact, 'the complexity or otherwise of abnormal mental structures depended primarily on the nature and composition of the corresponding social institutions, and not on the level of civilisation, as it is commonly assumed' and Jakovljevic argued that even 'primitive' cultures could often develop highly intricate sets of social relations. ${ }^{77}$

This was not merely an ideological distancing from the core tenets of Western European colonial psychiatry and colonially minded transcultural psychiatric concepts but also an attempt to reinterpret the long-standing and rather influential Freudian tradition of '[transposing] the racial assumptions of the cultural evolutionary scale onto the modern psyche. ${ }^{78}$ Jakovljevic's attempt at a Marxist re-interpretation of the West African subjectivity was thus crucially informed by his consideration of the position and developmental potential of socialist Eastern Europe on the global civilisational scale, and we can speculate that it was this cultural, geographical and ideological displacement of Jakovljevic himself as a Yugoslav psychiatrist in the 1960s that determined his distinctive take on the concept of primitivism in the context of postSecond World War international psychiatry.

\section{Revolutionary Personality and Mental Illness}

Jakovljevic's distancing from Freudian psychoanalysis spread to other aspects of his work as well. In his discussions of the definition of pathology and normality in different cultural contexts, Jakovljevic criticised exclusively psychological interpretations of mental disorders, which he thought disregarded the revolutionary potential of conflicts between individuals and their social

71 Ibid., 167.

72 Khanna, Dark Continents, 6.

73 See J. C. Carothers, 'A Study of Mental Derangement in Africans, and an Attempt to Explain Its Peculiarities, More Especially in Relation to the African Attitude to Life', East African Medical Journal, 25, 4 (1948), 142-66.

74 Jakovljevic, Prilozi za Socijalnu Patologiju, 162.

75 Littlewood and Lipsedge, Aliens and alienists, 66-7.

76 Jakovljevic., Prilozi za Socijalnu Patologiju, 168.

77 Ibid., 166.

78 Celia Brickman, Aboriginal Populations in the Mind: Race and Primitivity in Psychoanalysis (New York: Columbia University Press, 2003). 
environment: 'socially caused conflicts might constitute a progressive factor in the development of a society' and lead to revolutionary resistance against the social organisation or structure. ${ }^{79}$ This was a new platform for Marxist psychiatry and psychoanalysis, and it radically redefined the role of social conflict in causing mental illness. While a discord or conflict between an individual and her social environment (which traditional psychoanalysis tended to see as the core origins of neurotic disorders) might lead to mental pathology and personality deviation, pathological or pathogenic socio-cultural factors did not necessarily cause psychological disorders, if a robust individual in an 'abnormal' society found ways to overcome or affect the existing circumstances. Quite to the contrary, a 'conformist adaptation of an individual to an abnormal social environment might lead to an even more fundamental form of [psychological] abnormality'. In that sense what Jakovljevic defined as a 'non-conformist' personality was a phenomenon critically different from a mentally ill individual, although it did emerge from a similar structural setting. In fact, the natural conclusion of such reasoning was that the 'non-conformist personality' was the healthiest type of individual in any reactionary or 'anachronistic' society. Jakovljevic articulated his theory of revolutionary personality following his work in Guinea but based it on his research findings in both Africa and Yugoslavia. This is where universalism came to inform Jakovljevic's conception of comparative psychiatry: in order to evaluate the existence and intensity of mental disorder in a particular culture or society it was not enough to consider conflicts between individuals and broader structures; those very structures, environments and socio-political values needed to be assessed against a set of universal, 'objective' standards, which would mark them as progressive or otherwise.

Mental pathology developed if individuals clashed with the norms of a progressive society, but if a similar conflict occurred in a reactionary setting it was not necessarily a sign of an abnormal personality. If the person in question could not adapt to the anachronistic or 'decadent' demands of a non-progressive social environment, they could be seen as abnormal only if such conflicts were destructive, rather than constructive or progressive in a revolutionary sense. In fact, such intra-psychic conflicts need not lead to mental illness at all and might even result in the 'growth of personality and society, which happens precisely as a consequence of ever more complex internal conflicts and new solutions built into that society by the personality [in question]'. At the same time, 'absolute social adaptation to anachronistic and obsolete forms of sociability would necessarily impoverish and alienate the individual', and possibly push them into difficult neurotic disorders. $^{80}$

It was in this context of non-conformist and revolutionary personalities that Jakovljevic implicitly recognised one of the strongest connections between Eastern European and Guinean/ African experiences of dramatic social change. While revolutionary activity in wartime and postwar Yugoslavia established the foundations of the new state and was celebrated at every political, social and cultural level, Guinea had undergone comparable political experiences, primarily in the course of its recent decolonisation struggle which produced different forms of anti-colonial cultural and political expressions. According to Jakovljevic, this clearly demonstrated that 'pathogenic' social and political situations were not necessarily destructive because not all individuals would be broken by such potentially psychologically destabilising circumstances. To the contrary, certain personalities might be 'stimulated [by such illness-inducing settings] to develop creatively new forms of reacting (such as the creation of novel political forms in the context of fighting colonialism instead of conformist subordination) ${ }^{\prime} .{ }^{81}$ The creative potential embedded in social and political conflicts in certain types of societies, therefore, allowed both Yugoslavia and Guinea to turn possible psychological disorders into productive and progressive political behaviour, which fundamentally marked the profiles of both countries regardless of their

\footnotetext{
79 Jakovljevic, 'Prilog Proucavanju Neurotickih Poremecaja', 76.

${ }^{80}$ Jakovljevic, 'Prilog Proucavanju Neurotickih Poremecaja', 76-7.

${ }^{81}$ Jakovljevic, Prilozi za Socijalnu Patologiju, 163.
} 
dramatically different circumstances. It was in this theory of revolutionary personality and its complex relationship to mental illness that the original contribution of Yugoslavia's post-war Marxist psychiatry lay, and the comparative anthropological, ethnographic and psychiatric research conducted by Jakovljevic and his associates in Guinea and Europe played a crucial role in the development of this thesis. The experience of Guinean decolonisation confirmed Jakovljevic's conclusions drawn from Yugoslavia's and Eastern Europe's recent socialist revolutionary past. Moreover, it allowed the Yugoslav psychiatrist to generalise his Marxist-informed tenets regarding the role of social conflict in causing mental illness and to combine his transcultural research goals with politically salient explorations of the psychological impact of revolutionary environment or activity.

\section{Conclusion}

Discussing Africa and the developing world thus, for Jakovljevic, always meant discussing Eastern European developmental concerns: similarities and comparisons abounded, and it remained unclear whether, in Jakovljevic's mental universe and clinical conclusions, Yugoslavia had more in common with Africa or Western Europe. This shaped Jakovljevic's understanding of concepts such as 'primitivism' and civilisation, and even though he tacitly accepted the cultural and medical assumptions of the colonial psychiatric framework, he subscribed to a much more dynamic view of non-Western societies and cultural traditions. In this way he revised the traditional psychiatric, psychoanalytic and anthropological interpretations of non-European civilisations as inhabiting the childhood stage of the history of humankind, and insisted on Guinea's remarkable possibilities for progress and development. Perhaps precisely because Yugoslav psychiatry remained preoccupied with the purported primitivism of its own peasant and working-class population, Jakovljevic strove to make inferences regarding the cultural and psychological consequences of Guinea's extremely disruptive social(ist) transformation and attempted to frame his conclusions in a way that would be relevant for the far-reaching transformations affecting the Yugoslav society. For understandable reasons Jakovljevic was crucially interested in the psychological repercussions of radical social changes; his experiences in Guinea, where the period of decolonisation and quest for a local version of socialism was accompanied by seismic societal shifts, helped him develop a nuanced theory of revolutionary personalities and their roles in times of social and political disruption and uncertainty. In the context of Marxist psychiatry Jakovljevic's concept of revolutionary personality radically redefined the relationship between social conflict and mental illness, as he relied on anthropological, ethnographic and clinical evidence from both Yugoslavia and Guinea.

Jakovljevic's work and special position within the emerging discipline of transcultural psychiatry were thus marked by both his (and his home country's) political and ideological background, and the position of Yugoslavia on the cultural and political periphery of Europe. His involvement in transcultural psychiatry demonstrated the inherent contradiction of Eastern European Marxist psychiatry: its dubiously colonial 'civilising mission' towards the subalterns in its own populations and its progressive, emancipatory agenda. Jakovljevic's use of Africa as a testing ground for the relative significance of cultural and civilisational factors in the development of mental illness ultimately turned into an unprecedented opportunity to shed light on and attempt to resolve some glaring internal inconsistencies from Yugoslavia's own socio-political context. 